\author{
Alina Kowalczykowa* \\ Instytut Badań Literackich Polskiej Akademii Nauk
}

\title{
Kiedy Mickiewicz poznał Marylę?
}

\section{Streszczenie:}

Alina Kowalczykowa analizuje szczegółowo w swoim artykule biografię Adama Mickiewicza (1798-1855). Interesuje ją tutaj szczególnie wątek jego znajomości z Marylą Wereszczakówną (1799-1863) i właściwy okres zadzierzgnięcia przez nich pierwszej znajomości, która przerodziła się później w romantyczną miłość nabierając zarazem znamion legendy literackiej. Ich relacja wzbudza wciąż, zdaniem Kowalczykowej, żywe zainteresowanie oraz wątpliwości badaczy. Nie ma bowiem, przede wszystkim, zgody w kwestii podstawowej: kiedy się oni poznali, kiedy zakochali? Temat pozostaje zatem delikatny. Był zresztą w czasach wieszcza pomijany milczeniem. Wszelkie ustalenia wyrastają z rekonstrukcji wydarzeń, których (w imię dyskrecji) nikt porządnie nie opisywał. W rezultacie podstawę opowieści o miłości Mickiewicza oraz Wereszczakówny stanowią drobne wzmianki, czerpane z listów filomatów i ze wspomnień. Są przypadkowe i kalekie. Nie zawsze dają się złożyć w spójną całość.

Słowa-klucze: Adam Mickiewicz, Maryla Wereszczakówna, epoka romantyzmu, legenda literacka, miłość.

* Alina Kowalczykowa - prof. zw. dr hab., autorka licznych książek, m.in. Słowacki (Warszawa 1994); Dramat i teatr romantyczny (Warszawa 1997); Romantyzm. Nowe spojrzenie (Warszawa 2008); autorka opracowań kilku publikacji Biblioteki Narodowej, m.in. Idee programowe romantyków polskich. Antologia (Wrocław 1991). 


\section{When did Mickiewicz meet Maryla?}

\section{Summary:}

In her article, Alina Kowalczykowa analyses in detail the biography of Adam Mickiewicz (1798-1855). She is particularly interested in his relationship with Maryla Wereszczakówna (1799-1863) and the proper period of triggering their first acquaintance which later developed into romantic love, at the same time becoming a somewhat literary legend. According to Kowalczykowa, their relationship still raises keen interest and doubts among researchers since there is no unison towards the basic issue: when did they meet, when did they fall in love? The subject still remains delicate. Even throughout the poet's life it was the subject of silence. Any sort of arrangement is based on the reconstruction of events which (for the sake of discretion) nobody ever described properly. As a result, the basis for the story about Mickiewicz and Wereszczakówna's love comprises minor references drawn from Philomaths' letters and reminiscences. They are accidental and lame. It is not always possible to put them in coherent whole.

Key words: Adam Mickiewicz, Maryla Wereszczakówna, Romanticism, literary legend, love.

Osnuta na wydarzeniach życia Adama Mickiewicza legendowa opowieść o rozwoju jego uczucia do Marii Wereszczakówny znakomicie podtrzymuje poetycką wizję potęgi romantycznej miłości, zdolnej przenosić góry lub prowadzić do grobu z rozpaczy.

Narodziny miłości Adama i Maryli zbiegły się w czasie z narodzinami polskiego romantyzmu. Były żywym potwierdzeniem, że gwałtowne, podważające racjonalistyczną wizję świata wybuchy uczuć mogą przydarzać się nie tylko w świecie poetyckiej fikcji, lecz i w życiu realnym. Toteż dzieje tej miłości, początek i przebieg, wzbudzały i wciąż wzbudzają żywe zainteresowanie - i wątpliwości - badaczy. Nie ma, przede wszystkim, zgody w kwestii podstawowej: kiedy się poznali, kiedy zakochali? 
Temat jest delikatny, otaczany dyskrecją, wszelkie ustalenia wyrastają z rekonstrukcji wydarzeń, których (w imię dyskrecji) nikt porządnie nie opisywał. W rezultacie podstawę opowieści o miłości Maryli i Adama stanowią drobne wzmianki, czerpane z listów filomatów i ze wspomnień; są przypadkowe i kalekie, nie zawsze dają się złożyć w spójną całość. Jej początek jest utożsamiany z datą najdawniejszego wydarzenia, które udało się ustalić - jest nim spotkanie przyjaciół w należących do Wereszczaków Tuhanowiczach w sierpniu 1820 roku (Adam był tam wtedy przez dwa tygodnie). W Kronice $\dot{z} y$ cia... poety jest cytowany list Tomasza Zana donoszącego, że „razem z Adamem jak najmilej, jak najweselej cały tydzień przeszedł [...] z prawdziwie zacnymi i promienistymi Wereszczakami, z promienistą i najlepszą Marią, którą sam Adam uwielbia"1. W Polskim Słowniku Biograficznym (szkic pióra Zbigniewa Jerzego Nowaka) czytamy: „Pierwsze spotkanie Mickiewicza z Marylą nastąpiło w Tuhanowiczach prawdopodobnie w poł. sierpnia 1820. Podczas radosnych tygodni wakacyjnych [...] zrodziła się miłość w Mickiewiczu i Wereszczakównie, która była już wtedy narzeczoną Wawrzyńca Puttkamera"2.

Rozwinął temat Jarosław Marek Rymkiewicz w Encyklopedii Mickiewicza $a^{3}$ : „Pierwsi monografiści poety uważali, że Mickiewicz przyjechał do Tuhanowicz już w roku 1819, a nawet 1818 i że wówczas zakochał się w Maryli. Nie ma jednak na to żadnych dowodów"4, poznał ją „najprawdopodobniej w czasie swojej pierwszej ${ }^{5}$ wizyty w Tuhanowiczach w połowie sierpnia 1820 roku. Nie znaczy to, że już wówczas rozpoczął się ten najsłynniejszy polski romans, czy też że poetę z córką Wereszczaków od razu połączyło jakieś uczucie - początkowo może była to tylko młodzieńcza przyjaźń”. I dalej: „2/14 lutego 1821

1 List T. Zana do Onufrego Pietraszkiewicza z 23 sierpnia 1820, cyt. za: M. Dernałowicz, K. Kostenicz, Z. Makowiecka, Kronika życia i twórczości Mickiewicza. Lata 1798-1824, Warszawa 1957, s. 236.

2 Z. J. Nowak, Puttkamerowa z Wereszczaków Marianna Ewa, [w:] Polski Słownik Biograficzny, t. XXIX, red. E. Rostworowski, Wrocław 1986, s. 479-482.

3 J. M. Rymkiewicz, D. Siwicka, A. Witkowska, M. Zielińska, Mickiewicz. Encyklopedia, Warszawa 2001; hasło: Puttkamerowa Maria, opracował J. M. Rymkiewicz, s. 448-451.

4 Uzupełnijmy: żadnych obecnie znanych dowodów.

5 Brak uzasadnienia, dlaczego ta wizyta została określona jako pierwsza? 
roku Maryla wyszła za mąż za hrabiego Wawrzyńca Puttkamera. [...] $\mathrm{Z}$ istniejących świadectw można wywnioskować, że romans Mickiewicza i Maryli miał swój początek dopiero po jej ślubie z hrabią Puttkamerem, czyli gdzieś wczesną wiosną 1821 roku. [...] Romans trwał, z różnym natężeniem, do połowy roku 1823, jego apogeum przypada na jesień roku 1822"6.

Nie wydaje się słuszne połączenie daty pierwszego spotkania kochanków z najwcześniej odnalezioną notatką, najwcześniejszym „zachowanym świadectwem". Pewne wątpliwości może nadto wzbudzać wzmianka o nieustannej wesołości towarzystwa w tych dniach, w których ponoć Mickiewicz poznał Marylę i którą „uwielbia”, jak pisał Zan. Gdzież tu czas na miłosne zauroczenie? I skąd przeświadczenie, że co nie zostało zapisane i nie skomentowane, tego nie było?

Brak we wspomnianych biogramach odwołań do listów Maryli Wereszczakówny do Tomasza Zana, które znajdują się w Bibliotece Polskiej w Paryżu ${ }^{7}$. Nie sięgano do nich, mimo że są wymienione w nocie bibliograficznej w PSB. Są ważne. Stawiają bowiem pod znakiem zapytania ową wakacyjną datę, wyznaczającą sierpień 1820 roku jako moment poznania Maryli i Adama.

Kluczowe znaczenie ma według mnie list Maryli, oznaczony „7 lutego", bez daty rocznej. Maryla obyczaj wpisywania dat traktowała trochę po macoszemu; i tak najważniejszy list powstał po prostu „7 lutego”, „po świętach”, jak w nim zapisane. Czyli: po świętach bożonarodzeniowych. Którego roku? ${ }^{8}$

Adam Mickiewicz we wrześniu 1819 roku przeniósł się na stałe z Wilna do Kowna, gdzie ucząc w szkole podstawowej, odpracowywał koszty studiów. Święta Bożego Narodzenia 1819 roku spędził w Wilnie; przyjechał w wigilię, a 5 stycznia 1820 roku wrócił do Kowna. Jeśli poznali się dopiero w tymże 1820 roku w sierpniu, to ów obszerny list z 7 lutego nie mógł

6 Tamże, s. 449.

7 Dział rękopisów, dokumenty pliku nr 1003.

8 Dodajmy: w 1818 roku Mickiewicz spędził Boże Narodzenie w Solecznikach Wielkich, u zaprzyjaźnionego księdza Pawła Hrynaszkiewicza; w 1820 - w Wilnie, lecz nie było w nim wtedy Maryli. 
powstać wcześniej! - niż w roku 1821 (czyli w 5 dni po ślubie z panem Wawrzyńcem).

Pisała Maryla do Zana o swych smutnych przeczuciach, o melancholii, troszczyła się o zdrowie Mickiewicza: ,,jeżeli czuły jesteś na cierpienia Przyjaciół, poświęć choć krótki moment i napisz do mnie”, „teraz się tylko cieszę przypomnieniem drogich momentów przepędzonych w Wilnie. Już się nie spodziewam więcej doznawać podobnych słodyczy.” I dalej: „Jutro przyjedziemy z Mamą na ciągłe mieszkanie do Płużyn. [...] Mama uprzedza Panów z prośbą, abyście byli łaskawi przyjechać na wakacje do Płużyn (gdy da Bóg szczęśliwie doczekać lata). [...] Na czas oznaczony konie będą przysłane". Nazwisko Mickiewicza jest wspomniane dyskretnie, dopiero przy końcu listu:

Księgę którą zostawił Pan Mickiewicz będąc w Tuhanowiczach proszę Mu oddać. Słyszałam iż chorował po świętach ${ }^{9}$, zapewne z niezaszanowania się; trzeba aby czuwano nad Jego zdrowiem gdyż bardzo siebie zaniedbuje. Najżyczliwsza Przyjaciółka Maria.

PS. Przepraszam bardzo Pana Tomasza że go nudzę moją bazgraniną bez sensu lecz trudno wymagać porządku w pisaniu, gdy go od dawna nie ma już w głowie.

Kluczowe znaczenie mają tu oczywiście ustalenie daty rocznej oraz wzmianka o Wilnie. „Drogie momenty” przepędzone w Wilnie, wspominane „7 lutego", mogły dotyczyć tylko świąt grudniowych: Bożego Narodzenia 1819 roku, a wspominane były już po Nowym Roku, w roku 1820. Troska o zdrowie Adama zdradza istniejącą już pewną między nimi zażyłość.

Jeśli znali się już w końcu 1819 roku (a może i wcześniej), to porządkuje się układ późniejszych wydarzeń. Wzmianka z 7 lutego, powiadamiająca o ,jutrzejszym” wyjeździe z matką do Płużyn ${ }^{10}$, wskazuje na 8 lutego 1820 roku; wiosną tegoż roku Maryla - z matką - wybiera się stamtąd do Tuhanowicz, dokąd zaprasza na dłuższy pobyt wakacyj-

10 Majątki w Płużynach i w Tuhanowiczach należały do braci i matki Maryli. 
ny Tomasza i Adama. Brak natomiast jakiegokolwiek napomknienia o mężu, hrabim Puttkamerze; on również w sierpniu 1820 bawił wówczas wśród przyjaciół, w Tuhanowiczach Wereszczaków ${ }^{11}$. Ich ślub odbył się 2 lutego 1821 roku.

List Maryli z 7 lutego to dokument mocno podtrzymujący wysuniętą przeze mnie hipotezę, że poznali się wcześniej, przed datą sierpniową. Więc w roku 1819? Znane wcześniej fakty temu nie przeczą.

Według Nowaka, w kwietniu Maryla przebywała w należących do jej matki Płużynach; jeśli był to kwiecień 1820 roku, wszystkie wspomniane wydarzenia można ułożyć chronologicznie, mają sensowny przebieg. Boże Narodzenie 1819 roku oboje spędzili w Wilnie. 7 lutego 1820 roku Maryla wysłała list do Zana, a 8 lutego wyjechała do Płużyn, gdzie spędziła następne tygodnie. Potem przeniosła się do Tuhanowicz, gdzie w sierpniu 1820 roku gromadzą się i wesoło bawią przyjaciele.

Zgadzają się wszystkie daty. „Drogie momenty” w Wilnie w końcu 1819 roku, późniejsza melancholia smutnej Maryli, która co najmniej od grudnia 1819 roku znała Adama. Dzień 7 lutego odnosi się więc do roku 1820 roku, poprzedzał wakacyjne spotkanie w Tuhanowiczach.

W dniu 2 lutego 1821 roku odbył się w Tuhanowiczach ślub Marii Wereszczakówny z hrabią Wawrzyńcem Puttkamerem.

Uczucia Adama do Maryli były dobrze znane przyjaciołom i przez nich komentowane, toteż gdy w marcu tegoż roku Mickiewicz dopominał się o przysłanie mu do Kowna Cierpień młodego Wertera, Franciszek Malewski świadomie opóźniał wysyłkę: lękali się o niego, szeroko znane były pogłoski o fali samobójstw z miłości, które popełniano po lekturze Wertera. Zaniepokojona Maryla żądała, by w tłumaczeniu „poprawić wady Gotego ${ }^{12}$ (który zepsuł złym zakończeniem najpiękniejszy Romans). Nadaj więcej sentymentalności bohaterowi, aby ten zakładał swe szczęście na uczuciach serca i był najszczęśliwszym z ludzi, chociaż nie zdawał się nim być w oczach świata"13.

11 Zob. list Mickiewicza do Zana, Kronika..., dz. cyt., s. 237.

12 Pisownia za oryginałem.

13 Zawarte w liście wskazówki dotyczące podejmowanego tłumaczenia mogły równie dobrze być kierowane do Mickiewicza. 


\section{Bibliografia}

Dernałowicz Maria, Kostenicz Ksenia, Makowiecka Zofia, Kronika życia i twórczości Mickiewicza. Lata 1798-1824, Warszawa 1957.

Nowak Zbigniew Jerzy, Puttkamerowa z Wereszczaków Marianna Ewa, [w:] Polski Słownik Biograficzny, t. XXIX, red. E. Rostworowski, Wrocław 1986, s. 479-482. Rymkiewicz Jarosław Marek, Puttkamerowa Maria [hasło], [w:] Rymkiewicz Jarosław Marek, Siwicka Dorota, Witkowska Alina, Zielińska Marta, Mickiewicz. Encyklopedia, Warszawa 2001, s. 448-451.

Rymkiewicz Jarosław Marek, Siwicka Dorota, Witkowska Alina, Zielińska Marta, Mickiewicz. Encyklopedia, Warszawa 2001. 